\title{
ANALYSIS OF FAILURE CONDITIONS FOR A DYNAMICALLY LOADED COMPOSITE FLOOR SYSTEM OF AN INDUSTRIAL BUILDING
}

\author{
Piotr BERKOWSKI, Grzegorz DMOCHOWSKI, Jacek GROSEL, \\ Krzysztof SCHABOWICZ, Zbigniew WÓJCICKI \\ Department of Civil Engineering, Wroclaw University of Technology, Pl. Grunwaldzki 11, 50-377, \\ Wroclaw, Poland
}

Received 26 Nov. 2012; accepted 18 Feb. 2013

\begin{abstract}
Results of examination and analysis of cracks formation in a composite slab floor in an industrial warehouse hall is presented in the paper. During exploitation of the floor, on which lift trucks and presses worked, a lot of deep cracks occurred in the slab. In order to define characteristics of cracks and properties of concrete there were made different NDT examinations. Measurements of vibrations due to work of presses were also realized with aim to evaluate their possible influence on cracks formation. Static, dynamic and strength structural calculations were also made based on the model of continuous, multi-bay plate. They showed that applied slab reinforcement was sufficient and acting loads did not have to cause cracks. After 3D modelling of the building and taking into consideration the flexibility of main steel beams it was gained that in the RC floor slab over supports bending moments could occur nearly three times greater than calculated from the 2D model. Taking into consideration wrong structural model of the building led to over-loading of the floor slab, its cracking and caused a necessity of its strengthening.
\end{abstract}

Keywords: industrial steel hall; composite RC/steel floor slab; cracks; static and dynamic modelling.

Reference to this paper should be made as follows: Berkowski, P.; Dmochowski, G.; Grosel, J.; Schabowicz, K.; Wójcicki, Z. 2013. Analysis of failure conditions for a dynamically loaded composite floor system of an industrial building, Journal of Civil Engineering and Management 19(4): 529-541.

http://dx.doi.org/10.3846/13923730.2013.779319

\section{Introduction}

Multi-storey warehouse industrial buildings of a light structure with floor systems of reinforced concrete slabs or composite steel/concrete slabs supported by high-span steel floor girders have been engineered and constructed more and more often in recent years (Fig. 1). A detailed static analysis, often including non-linear effects, the flexibility of components and their interactive cooperation, and also a dynamic analysis due to heavy traffic of transport vehicles, all these need to be considered while designing such hall-type buildings. A lack of such analyses or of calculations taking into account the aforementioned effects may lead to damages in building structure requiring repairs and reinforcement.

\section{General description of industrial building under analysis}

The floor system under investigation is located above the ground floor of a two-storey hall constructed for a warehouse of electronic finished products. The dimensions of the examined projection, marked off by segment expansion joints, are $91.5 \times 100.0 \mathrm{~m}$, and the total roof peak of the building is $16.3 \mathrm{~m}$. The level of the floor system of the ground floor is $6.0 \mathrm{~m}$ above the ground.

The load bearing structure of the ground floor consists of I-section steel plate columns arranged over a rectangular grid with main dimensions of $8.0 \times 10.0 \mathrm{~m}$, on which some columns are located transversely at irregular distances every 9.2, 9.5 and $10.0 \mathrm{~m}$.

Ground floor columns are of the section $350 \times$ $350 \times 12 \times 9 \mathrm{~mm}$, while columns extended to the second storey have the section of $428 \times 407 \times 20 \times 35 \mathrm{~mm}$. The columns which support roof girders are composed of two parts interconnected with bolts. Some outermost columns are extended from ground floor to the second storey and are used to support roof plate girders. The span of main roof girders is $54.0 \mathrm{~m}$. Plates of roof girder are of various cross-section height and widths and also wall thickness: from $1240-1540 \times 350 \times 12 \times$ $20 \mathrm{~mm}$ to $2050-1950 \times 400 \times 12 \times 25 \mathrm{~mm}$.

In the transverse direction of the hall, ground floor column capitals are connected with plate girder

Corresponding author: Piotr Berkowski

E-mail: piotr.berkowski@pwr.wroc.pl 


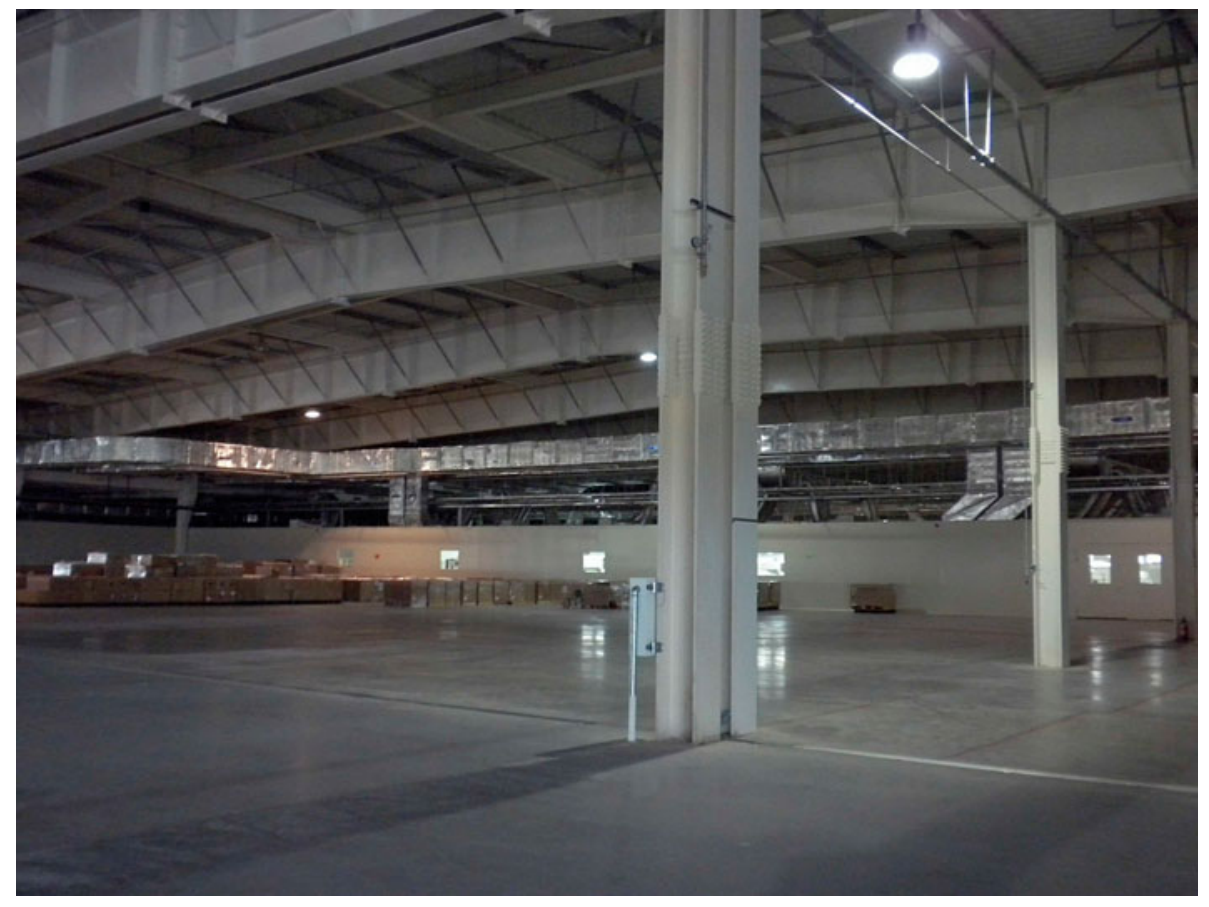

Fig. 1. General view of steel-bearing structure of the industrial hall

binding joist which support welded floor beams interconnected with plate girders by means of bolts. Plate girders are continually supported on the columns.

These beams were used to construct the steel/ reinforced concrete floor system under investigation (Fig. 2). Main binding joists with the span of 8.0 and $9.2 \mathrm{~m}$ have a cross-section of $700 \times 300 \times 13 \times 24 \mathrm{~mm}$, those with the span of $9.5 \mathrm{~m}-792 \times 300 \times 14 \times 22 \mathrm{~mm}$, and those with the span of $10 \mathrm{~m}-800 \times 300 \times 14 \times 26 \mathrm{~mm}$. The floor system beams are $10.0 \mathrm{~m}$ long and their cross-section is $606 \times 201 \times 12 \times 20 \mathrm{~mm}$. Dimensions of cross-sections are given according to design documentation available and are verified by measurements taken.

The floor system applied in the building is of the composite deck slab type (e.g. Crisinel, O'Leary 1996; Johnson 2004) constructed from a monolithic reinforced concrete load bearing slab reinforced with

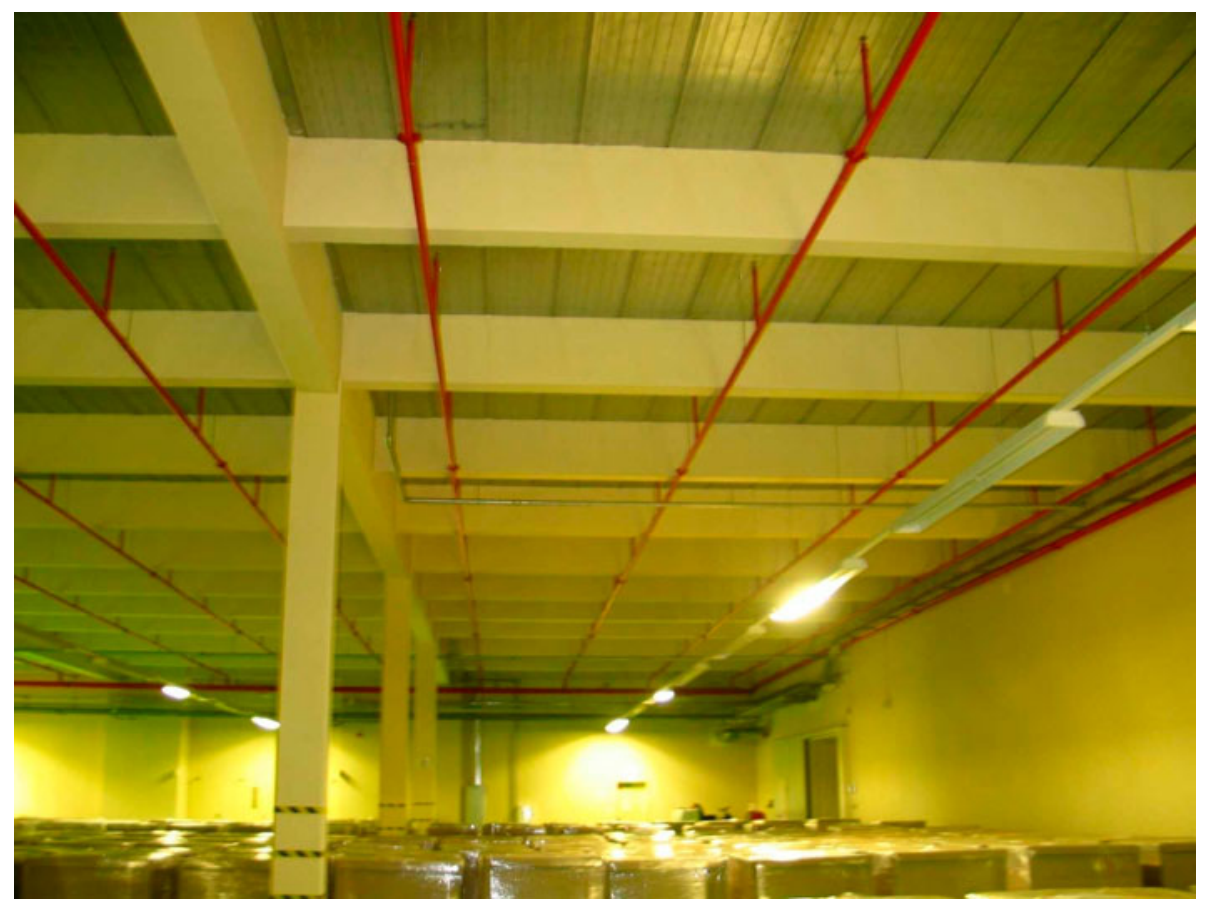

Fig. 2. View of the system of main and secondary floor beams 


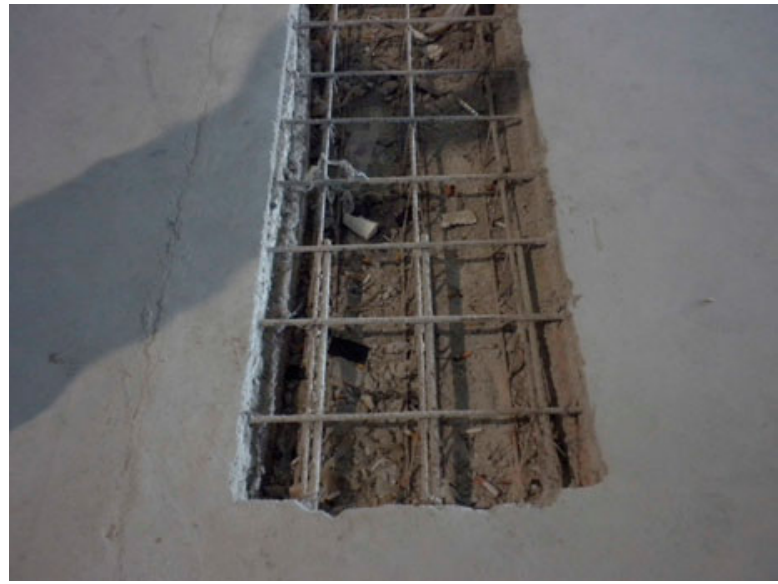

Fig. 3. View of the spatial trusses of composite deck slab

prefabricated spatial trusses welded to a troughed sheet laid on steel carrying girders (Fig. 3).

Lower bars of trusses are of diameter $d=8 \mathrm{~mm}$, and the upper bars are of $d=10 \mathrm{~mm}$. These bars are interconnected with diagonal braces $d=5 \mathrm{~mm}$ in diameter.

A grid of bars $d=10 \mathrm{~mm}$ and mesh $20 \times 20 \mathrm{~cm}$ is added. Over the floor beams, additional bars, $d=14 \mathrm{~mm}$ were placed on the top, with the reach of 40 diameters beyond the beam axis. The design and real thickness of the deck plate in the hall area under consideration is $15 \mathrm{~cm}$ (Fig. 4).

According to information read out of data plates, the nominal service load of the deck plate was assumed to be $8 \mathrm{kN} / \mathrm{m}^{2}$. An area of the hall deck plate was separated as production space where four (4) presses, $60 \mathrm{kN}$ mass each, were arranged and spaced approximately every $5.0 \mathrm{~m}$. Adjacent fields of the deck plate are used to store the fabricated products. Materials are transported with fork-lift cars whose total weight, including load, is approximately $30 \mathrm{kN}$.
As a result of these operational loads, the deck plate of the hall, in the outlined area and in adjacent fields, sustained extensive cracks (Fig. 5). Following the occurrence of cracks in the deck, some warehoused products were removed from it and the fork-lift trucks were eliminated.

\section{Technical condition of the deck plate}

In the course of operation, a large number of cracks were found in the floor system under examination. These cracks formed at the top surface of the deck slab and most often were located in parallel to the floor ribs and main beams (Fig. 5). There were also cracks transverse to the floor beams and a substantial number of cracks run along the reinforcement lines of deck slabs.

Acoustic measurements showed that some cracks went through the whole floor slab thickness, reaching its bottom surface. Internal cracks were also detected at contact planes between concrete and steel profiles (e.g. Chang et al. 2006; Dudziński et al. 2011; Valivonis 2006).

Measurements of crack openings and their depth were taken using Impact-Echo method during examinations. According to these measurements, the crack opening was up to $1.6 \mathrm{~mm}$, hence it was much higher than the admissible value of $0.3 \mathrm{~mm}$.

Visual inspections were also made for bolted connections of floor beams with binding joists, areas where binding joists bear on columns (in both cases, after removing gypsum board cladding), and also bolted connections of load bearing column segments with roof girders. No visible damage was found both in bolted and welded connections. The diameters of reinforcing bars and their spacing were measured in the test pits of floor slab. Examinations revealed that the concrete is of the C25/30 class, the steel is AIIIN

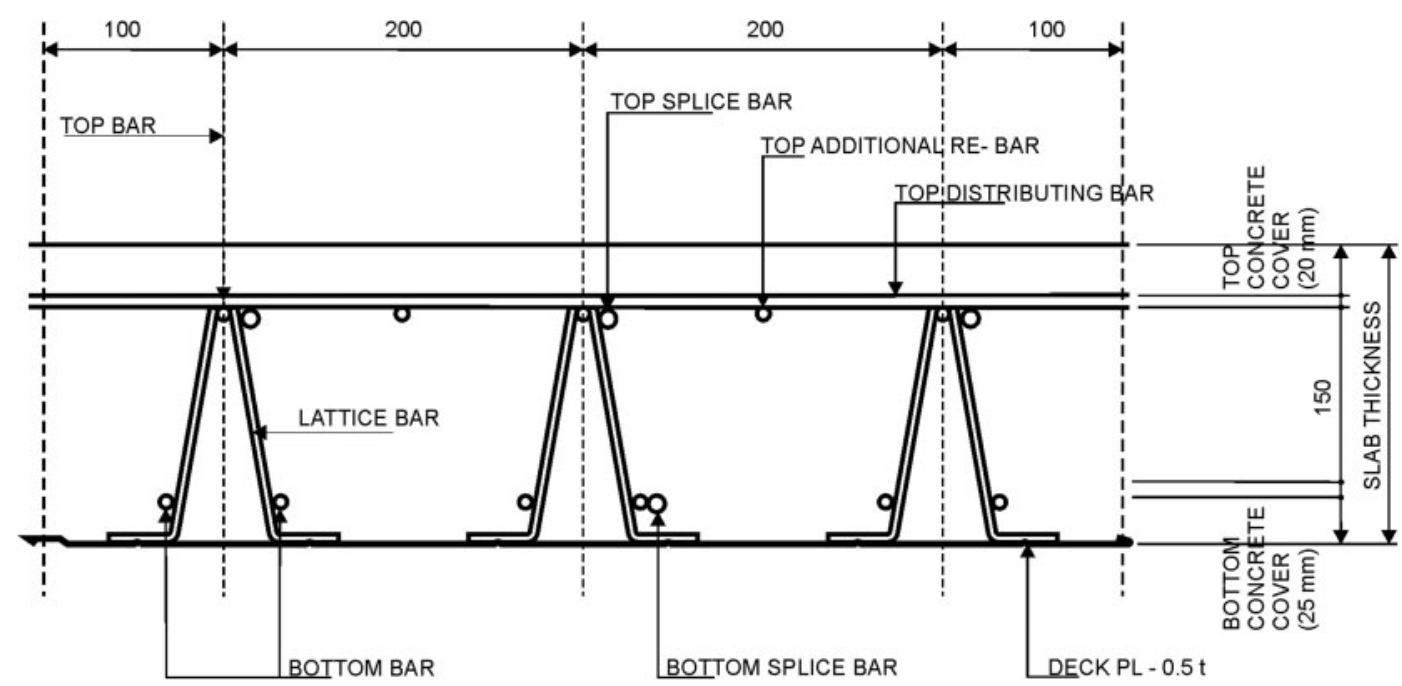

Fig. 4. Cross-section of the typical composite deck plate 


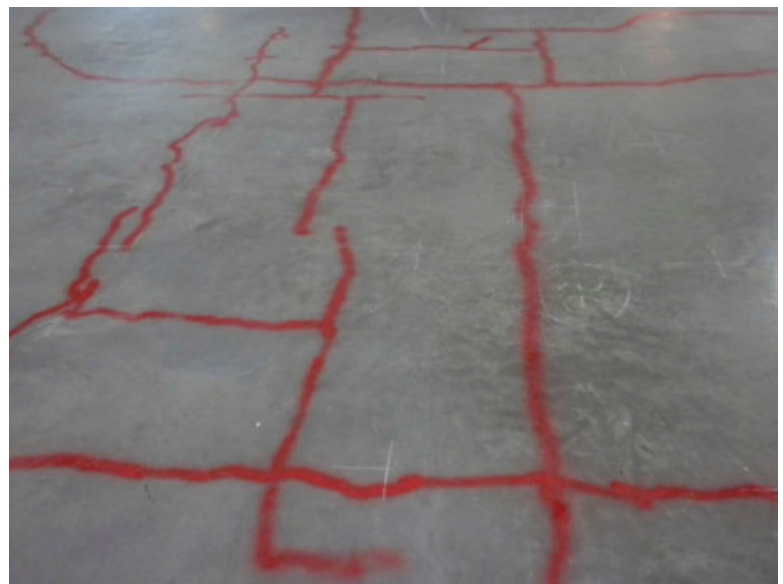

Fig. 5. View of the situation of cracks in concrete floor slab

with $f_{y k}=500 \mathrm{MPa}$, and these are the values consistent with those of design documentation.

Results of the first stage of investigation of the analyzed floor system were presented by Dmochowski et al. (2010).

\section{Non-destructive testing performed}

\subsection{Instrumentation used in testing}

First of all, the deck plate was examined with the Capo-Test non-destructive testing set used to evaluate the concrete compressive strength. Testing was run using the 'pull-out' method according to ASTM C900-06:2006, Bungey et al. (2006), PN-EN 125043:2006 and PN-EN 13791:2008.

For auxiliary purposes, the Covermaster CM 52 instrumentation was also used to locate the reinforcement bars inside the components under testing. Then, the Impact-Echo measuring set was used to test the defects in the concrete structure (Felicetti 2010; Gorzelańczyk 2011a, b, 2012; Goszczyńska et al. 2012; Hoła et al. 2011; Hoła, Schabowicz 2005a, b, 2010; Report ACI 228.2R-98 1998; Sansalone, Streett 1997; Schabowicz, Hoła 2012; Stawiski 2012).

\subsection{Outline and range of testing}

Three measuring areas were set up on the composition deck plate. Reinforcements were located according to the working documentation and, additionally, using the Covermaster CM 52 unit. One test with a CapoTest measuring set was performed in each measuring area. The expected concrete compressive strength was $50 \mathrm{MPa}$, hence a correlation relationship given by following equation was assumed, according to PN-EN 12504-3:2006:

$$
f_{c, c u b}=1.41 P-2.82
$$

where $f_{c, c u b}$ - cubicle concrete compressive strength (MPa); $P$ - extraction force $(\mathrm{kN})$.
The Impact-Echo non-destructive testing apparatus was used to determine the depth of cracks in the deck plate. Six cracks, each about $2000 \mathrm{~mm}$ long, were tested. The total amount of measurement points was approximately 100 . At each of these points an elastic wave was generated by means of an inductor placed on the head of the Impact-Echo unit, and the amplitude image of this wave was simultaneously recorded in time domain. At points suspected of damages, the testing was performed in greater detail by increasing the number of measurements (excitations of elastic wave) to find whether there is a defect or whether the concrete quality is correct.

\subsection{Results of testing and their analysis}

Results of the non-destructive analysis of the concrete of deck plate are summarized in Table 1, whereas Table 2 provides the evaluation of the real concrete class according to PN-EN 13791:2008. The age of the concrete at the moment of testing was over two years.

The depth of superficial cracks (Alam et al. 2012; Breysse et al. 2011; Głodkowska 2011; ŁowińskaKluge, Błaszczyński 2012) was also examined during testing. Figure 6 illustrates the characteristic geometry of superficial cracks, while Figure 7 shows the scheme

Table 1. 'Pull-out' test results (Capo-Test) for the deck plate under examination

\begin{tabular}{lcc}
\hline & $\begin{array}{c}\text { Extraction force } \\
(\mathrm{kN})\end{array}$ & $\begin{array}{c}\text { Compressive strength } \\
(\mathrm{MPa})\end{array}$ \\
\hline CT 1 & 27.1 & 35.39 \\
CT 2 & 26.5 & 34.54 \\
CT 3 & 27.9 & 36.52 \\
Average compressive strength & 35.48 \\
$\left(f_{\text {cm, ist }}\right)$ & \\
\hline
\end{tabular}

Table 2. Evaluation of real concrete class

\begin{tabular}{lc}
\hline Description & Strength \\
\hline Average compressive strength of concrete & 35.48 \\
The lowest compressive strength measure & 34.54 \\
The specific compressive strength of concrete is, & \\
$\quad$ according to ASTM C900-06:2006, the lower & \\
of the two following values: & \\
$f_{\text {ck, ist }}=f_{\text {cm, ist }}-k=35.48-7$ & \\
(variable $k$ for the number of results from 3 to & 28.48 \\
$\quad 6$ is 7 ) & \\
$f_{\text {ck, ist }}=f_{\text {ist }, \text { lowest }}+4=34.54+4$ & \\
$f_{\text {ist, lowest }}-$ the lowers compressive strength of & 38.54 \\
$\quad$ concrete in the structure & \\
Specific compressive strength of concrete & 28.48 \\
Standard deviation & $1.00 \mathrm{MPa}$ \\
Variability coefficient & $2.8 \%$ \\
Class of concrete compressive strength & $\mathrm{C} 25 / 30$ \\
\hline
\end{tabular}




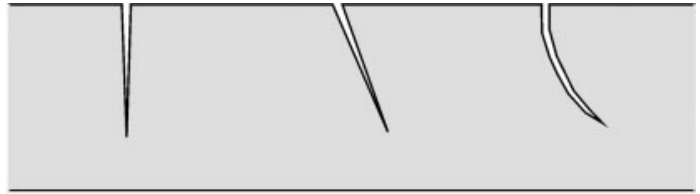

(a)

(b)

(c)

Fig. 6. Scheme of the characteristic geometry of cracks (Sansalone, Streett 1997): (a) perpendicular; (b) inclined; (c) curved

of measuring the opening crack depth using ImpactEcho instruments.

Table 3 provides parameters used to determine the depth of individual low-length cracks in the deck plate using Impact-Echo method for, as an example, two selected cracks parallel to the deck plate ribs. The table includes the average depth of cracks calculated from measurements taken. Attention should be drawn to the fact that the majority of cracks occurred over the top reinforcement bars as found according to the examination of reinforcement arrangement within crack areas.

The following conclusions were drawn on the grounds of the performed measurements and tests, the results of non-destructive testing using such instruments as Capo-Test, Covermaster and Impact-Echo.

All selected measuring areas were considered independently and all the results were considered to be representative ones:

(1) Estimated current class of concrete compressive strength (at the moment of testing) can be evaluated to be $\mathrm{C} 25 / 30$;

(2) The opening width of cracks is up to $1.6 \mathrm{~mm}$;

(3) Making use of Impact-Echo apparatus, it was found that the depths of non-through cracks in the deck plate are at least from 30 to $125 \mathrm{~mm}$.

\section{Dynamic testing}

In order to find out the possible causes of cracks formation due to dynamic influence of presses situated on the floor, the vibrations on the facility were measured for various operating modes of the presses (Fig. 8).

Measurements were taken in two stages. In the first one, deck plate vibrations in the 'clean', i.e. production part were taken. The purpose of this stage was to determine the vibration levels for machines and
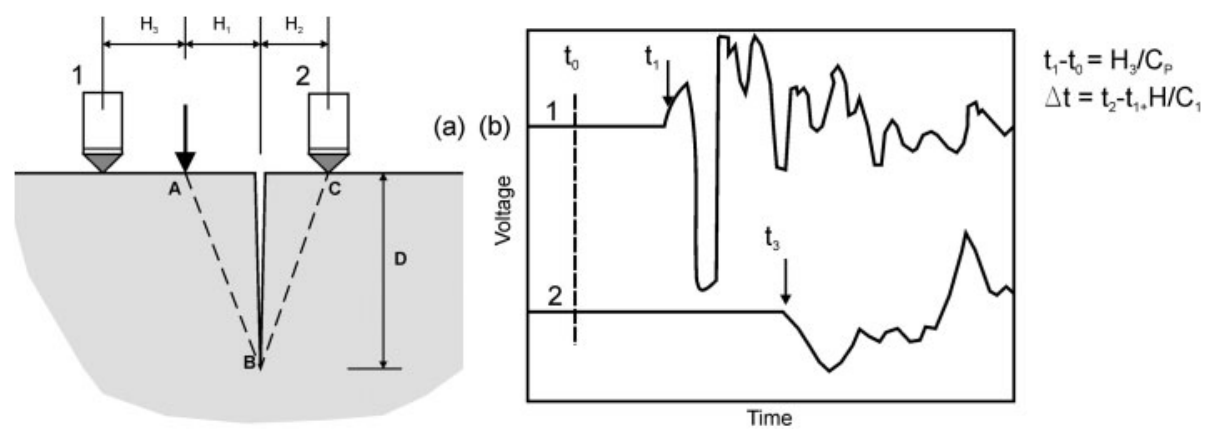

Fig. 7. Measurement of the opening crack depth: (a) scheme of the measurement; (b) sample waveform (Sansalone, Streett 1997)

Table 3. Parameters used for testing the deck plate using Impact-Echo apparatus to determine the depth of cracks

\begin{tabular}{|c|c|c|c|c|}
\hline $\begin{array}{l}\text { Velocity of wave in } \\
\text { floor slab }(\mathrm{m} / \mathrm{s})\end{array}$ & Crack number & $\begin{array}{l}\text { Crack opening } \\
\text { width }(\mathrm{mm})\end{array}$ & $\begin{array}{c}\text { Distance of test point on } \\
\text { the crack }(\mathrm{mm})\end{array}$ & $\begin{array}{l}\text { Depth of cracks (average value } \\
\text { of measurements) (mm) }\end{array}$ \\
\hline \multirow[t]{5}{*}{3320} & $\begin{array}{l}\text { R2 (crack along longer } \\
\text { side of the hall) }\end{array}$ & up to 1.6 & 0 & $86,84,88$ \\
\hline & & & 500 & $66,67,70$ \\
\hline & & & 1000 & $92,88,84$ \\
\hline & & & 1500 & $77,84,71$ \\
\hline & & & 2000 & $92,86,101$ \\
\hline \multirow[t]{5}{*}{3320} & $\begin{array}{l}\text { R3 (crack along longer } \\
\text { side of the hall) }\end{array}$ & up to 1.6 & 0 & $53,51,56$ \\
\hline & & & 500 & $70,64,64$ \\
\hline & & & 1000 & $103,88,71$ \\
\hline & & & 1500 & $64,56,62$ \\
\hline & & & 2000 & $94,125,84$ \\
\hline
\end{tabular}




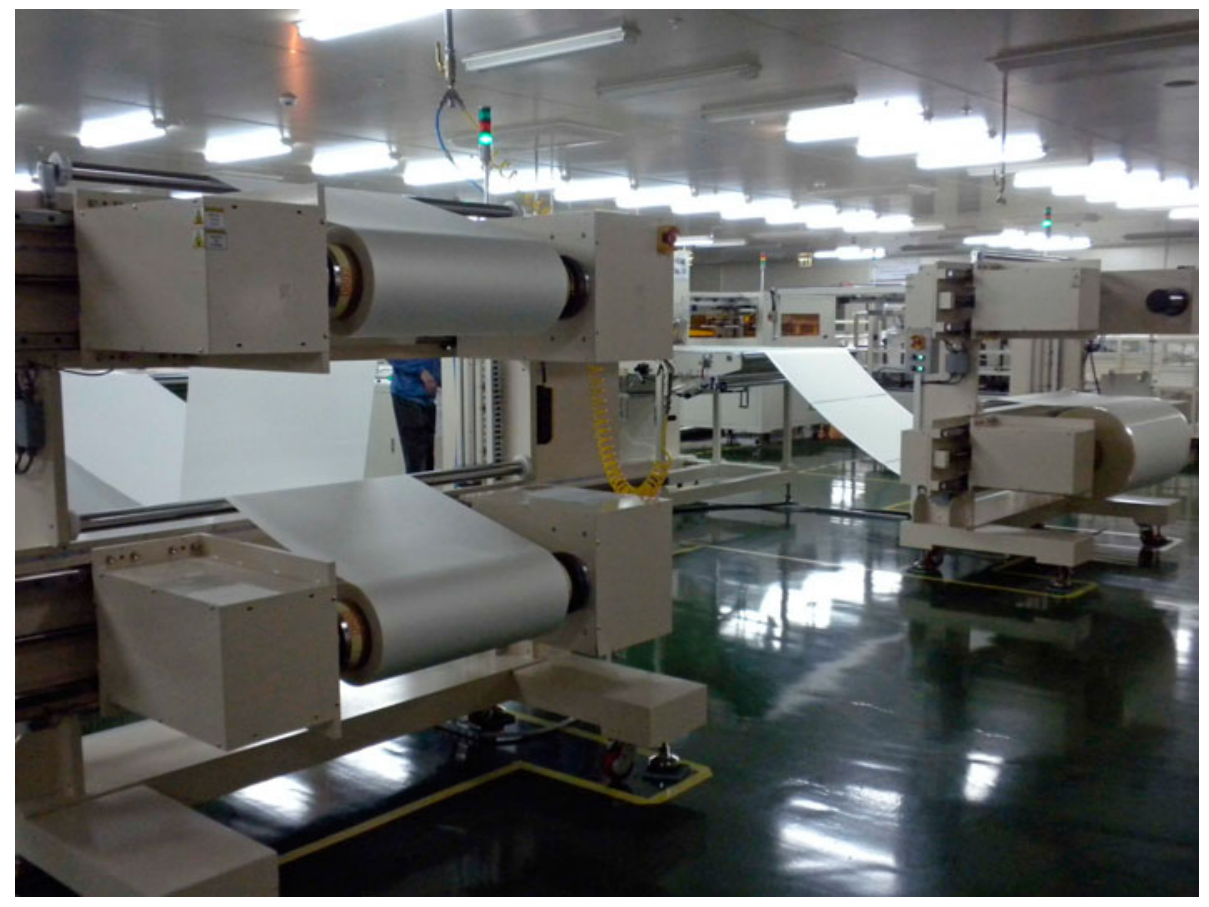

Fig. 8. General view of position of presses

for the deck plate close to the machines. Piezoelectric accelerometers, type 4507 B005 Bruel and Kjaer with the sensitivity of $0.1 \mathrm{~V} / \mathrm{ms}^{2}$, were used in these measurements. During the second stage, deck plate vibrations in the warehouse area with cracks in it were determined.
In this part of testing, the deck plate vibration levels were found and an analysis was carried out to determine the modal parameters of the structure (Andersen et al. 2008; Ewins 2000; Jacobsen et al. 2008). As the vibration levels in the warehousing area were lower, seismic accelerometers, type 8340 Bruel

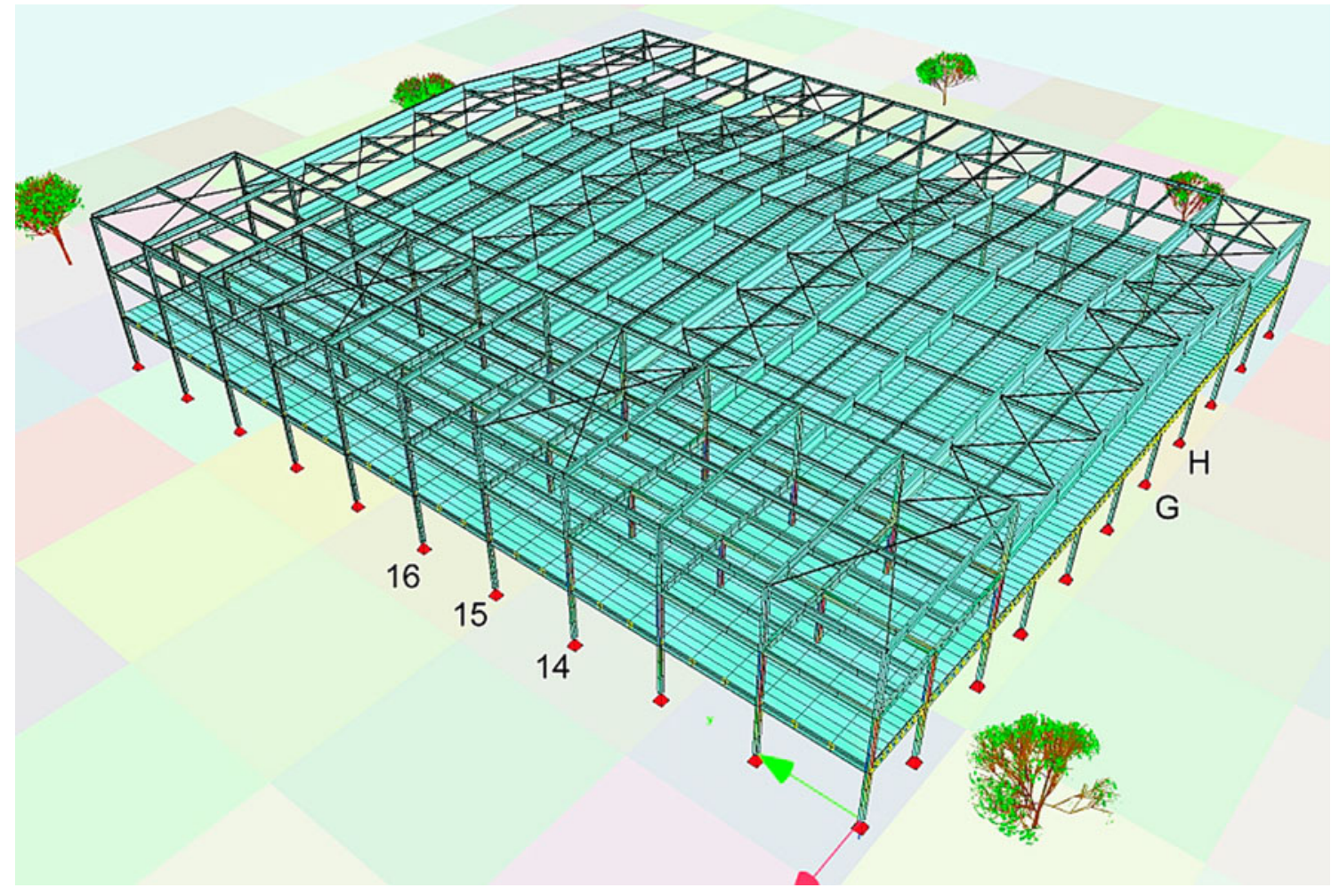

Fig. 9. General computer model of the industrial hall 


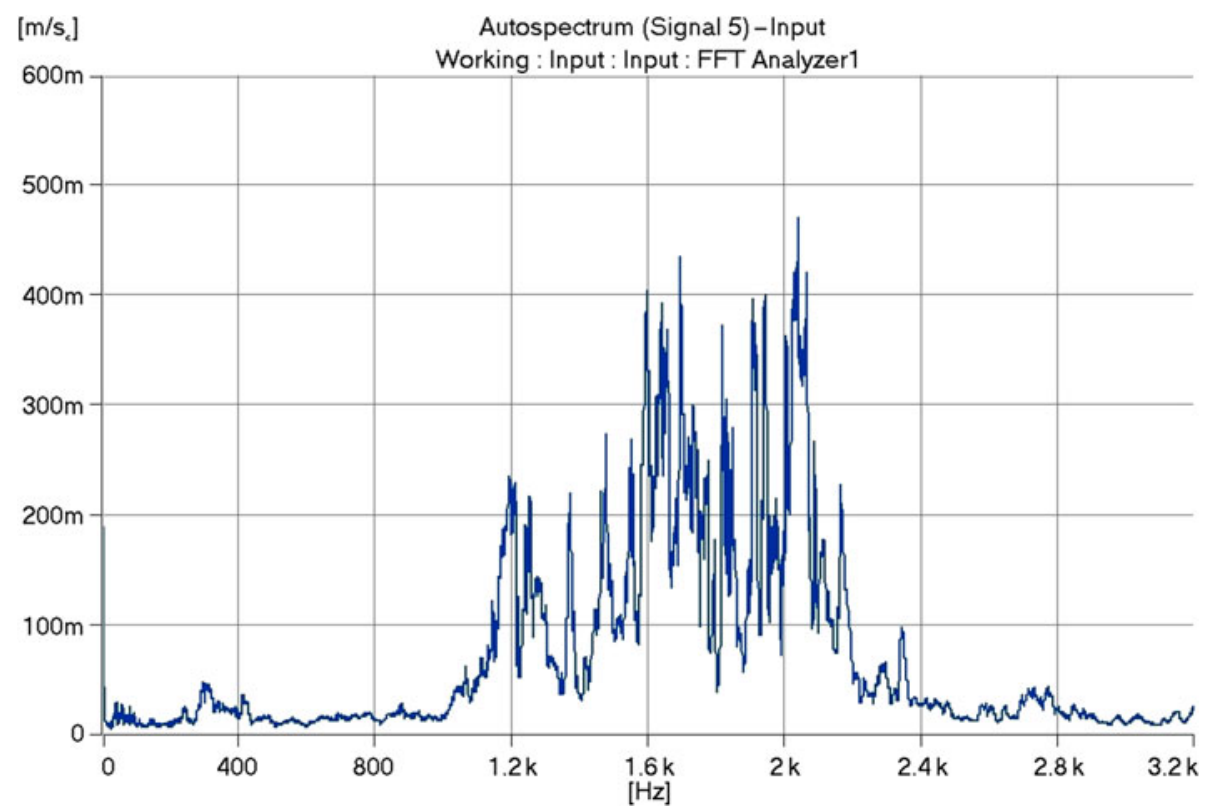

Fig. 10. Autospectrum of Signal 5, vibration of the working press number 2

and Kjaer with sensitivity of $1 \mathrm{~V} / \mathrm{ms}^{2}$, were used. In both stages, the 34-channel PULSE system capable of analyses from 0 to $25.6 \mathrm{kHz}$ was applied for measurements and analyses. This system is designed for versatile measurements and analyses of the dynamics of large engineering structures.

Also, a dynamic analysis was performed for the whole structure (Fig. 9) using the finite element method, which results are presented in Chapter 6.

\subsection{Test results for the Stage 1}

Figure 10 illustrates autospectrum of accelerations measured on the running machine. The frequencies within 1000-2200 $\mathrm{Hz}$ are dominating, and the maximum acceleration values found exceed $100 \mathrm{~m} / \mathrm{s}^{2}$.

Accelerations measured on the deck plate structure close to the machine supporting point were definitely lower - up to $2 \mathrm{~m} / \mathrm{s}^{2}$. The nature of vibrations is shown in Figure 11. The periodical pulse nature of the input function is visible. The time distance between excitation pulses is $4.8 \mathrm{~s}$.

As it can be seen, vibrations are subject to amplification in the system around $8-9 \mathrm{~Hz} ; 18-20 \mathrm{~Hz}$; 31-35 Hz; and $55 \mathrm{~Hz}$ (Fig. 12).

The influence of vibration on people was also determined according to PN-88/B-02171:1988 and the

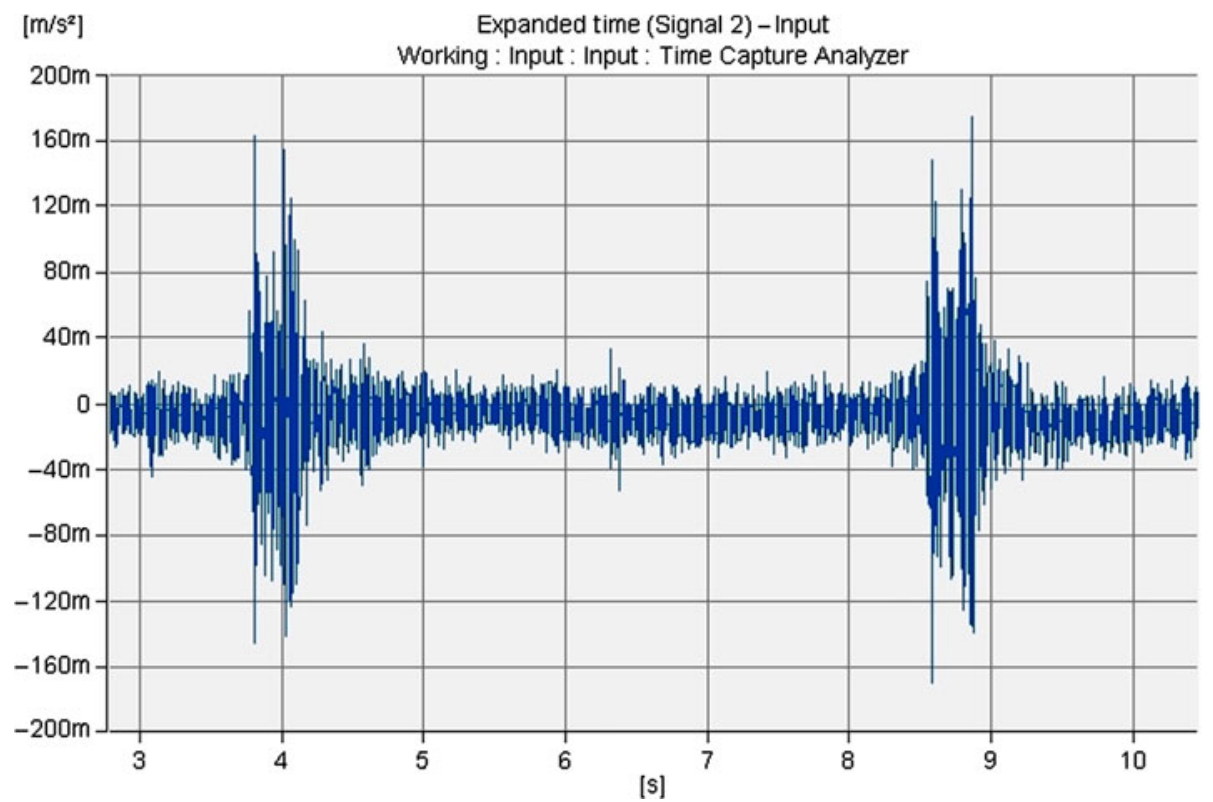

Fig. 11. Acceleration measured on the press 2 (Signal 2) 


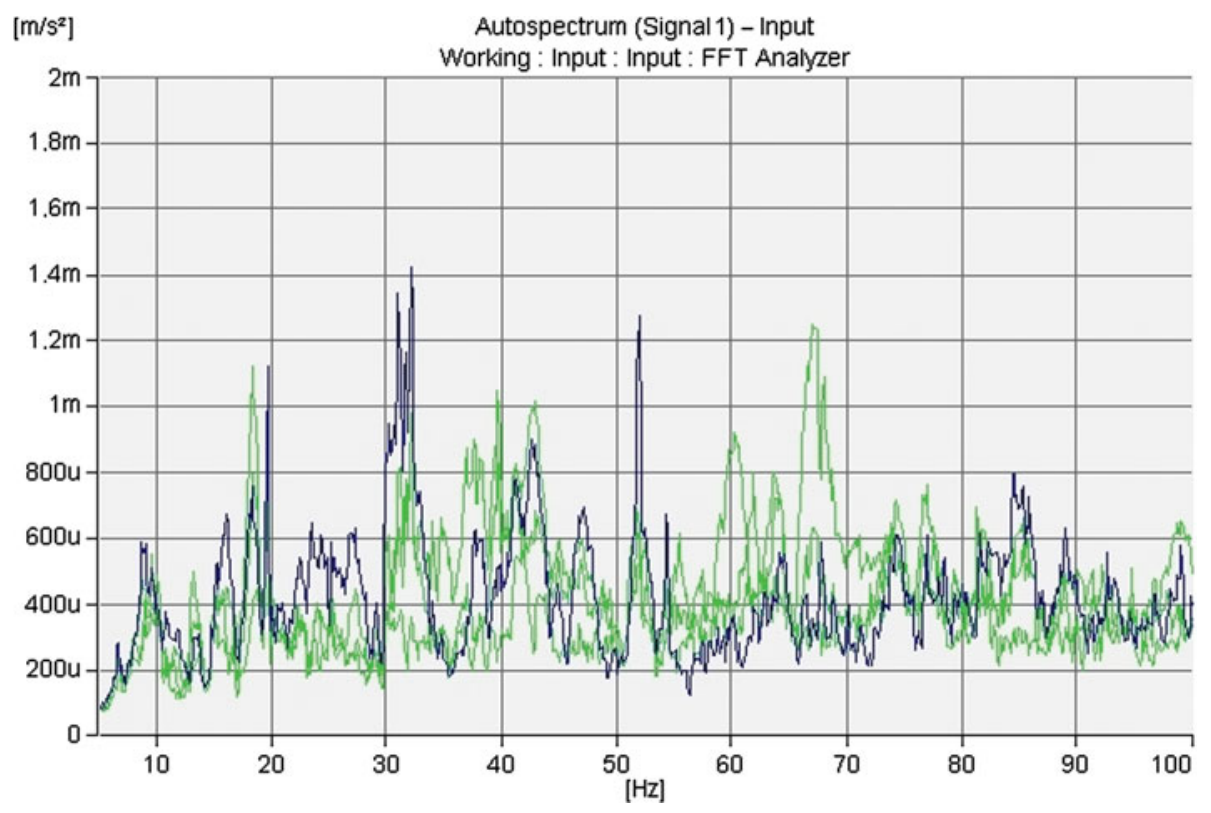

Fig. 12. Autospectrum of signals in bandwidth 5-100 Hz (Signal 2 - blue line)

results of the third analysis are shown in Figure 13. In thirds $8-80 \mathrm{~Hz}$, vibrations exceed the human being perception threshold, whereas in the $40 \mathrm{~Hz}$ third, this threshold is exceeded over eightfold.

These are vibrations with the level higher than that admissible by the standard PN-88/B-02171:1988 in working plants for continuous vibrations.

\subsection{Test results for Stage 2}

Several arrangements of accelerometers were used to take measurements during the Stage 2. Deck plate accelerations were measured at points located along the axis 15 and along the line between axes 14 and 15 (Fig. 9). The accelerations recorded were up to $0.7 \mathrm{~m} / \mathrm{s}^{2}$. The largest amplitudes occurred in the medium part of deck plate (between axes $\mathrm{G}$ and $\mathrm{H}-$ Fig. 9). The closer the measuring point was to the external walls, the lower was the amplitude.

The vibrations measured in points between axes were of higher amplitudes than vibrations along the axes. Vibrations were also measured in two points close to each other located on two sides of the crack on the warehouse deck plate.

The spectrum of accelerations is shown in Figure 14. Small differences in the autospectrum suggest the conclusion that the crack 'does not operate dynamically', that is, the cracks were not created by dynamic effects.

The Operational Modal Analysis for the structure segment in the rectangle marked out by the $\mathrm{G}-\mathrm{H}$ axes and the 14-15 axes (Fig. 8) was also carried out in the Stage 2; here the accelerometers were placed in the $3 \times 3$ wall (Fig. 15). The values of accelerations taken were lower than those in the close vicinity of the machines, the sources of vibrations.

Figure 16 illustrates the autospectra of acceleration in the bandwidth $0-100 \mathrm{~Hz}$. Intensification is visible close to the frequency of $9 \mathrm{~Hz}$.

To run the modal analysis, the software package of SVS Company, Denmark, was applied and Frequency Domain Decomposition was used. The form for fundamental vibration frequency is shown in Figure 17. Following a series of measurements, it was finally ascertained that the value of eigenfrequency of the floor slab is $9.27 \mathrm{~Hz}$.

As (according to the standard PN-90/B03200:1990) for a public building with steel deck plates over $12 \mathrm{~m}$ in span (if there are no partition

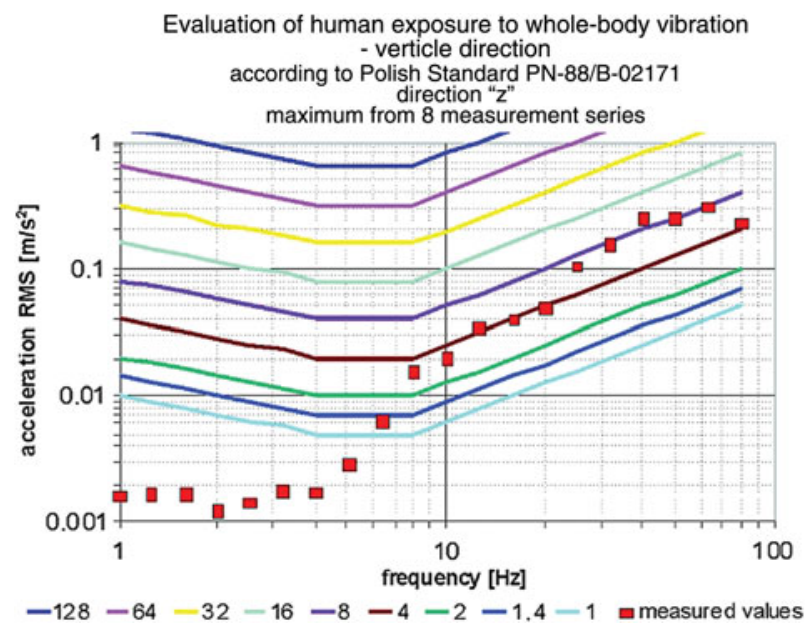

Fig. 13. RMS of acceleration $-1 / 3$ octave analysis on the background of human sensitive limits 


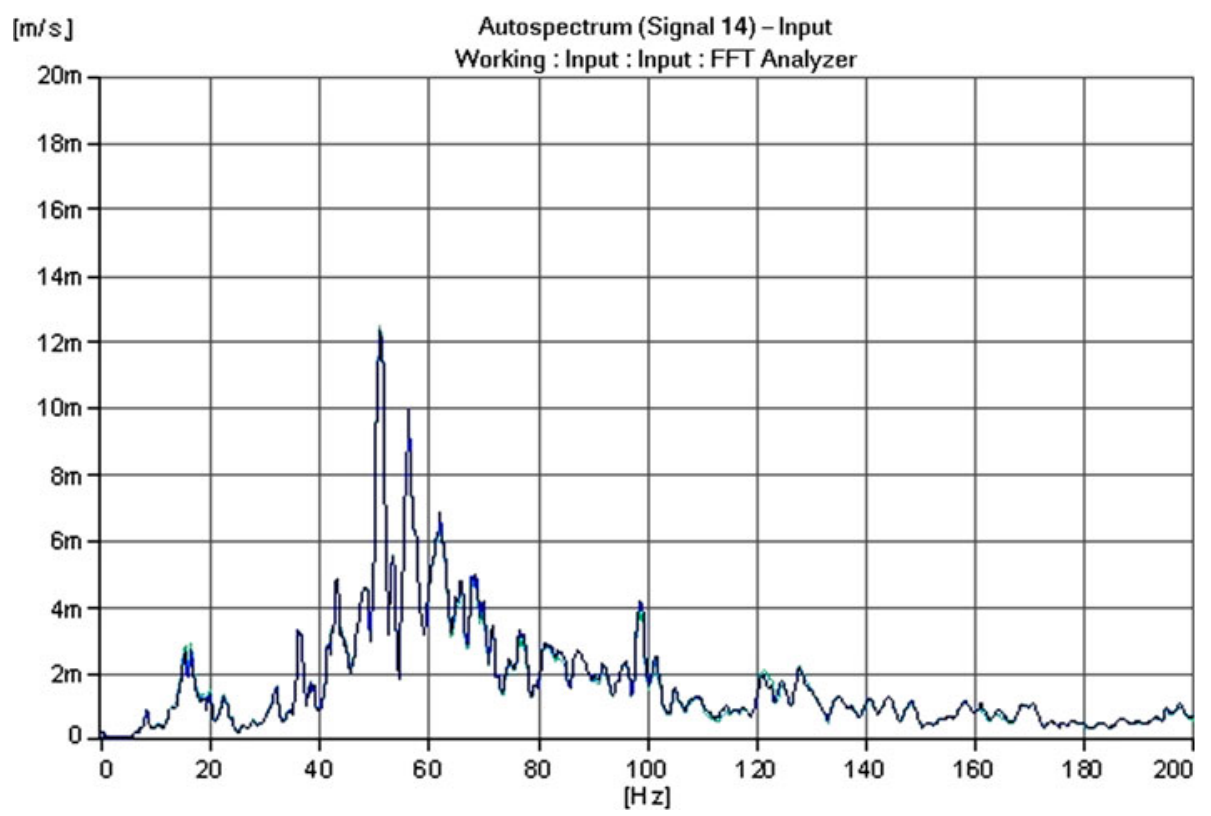

Fig. 14. Autospectrum of two signals measured on both sides of the crack

walls on the floor), the fundamental eigenfrequency should be at least $5 \mathrm{~Hz}$. It was acknowledged that this standard requirement is met.

\section{Numerical analysis of the hall structure}

Upon completing verification measurements of the facility geometry, carrying out test pits and material examinations, and following a review of the technical documentation available, the conclusion was drawn that the concrete deck plate under examination was made in accordance to the working design. This design documentation assumed the working load of the slab to be $8 \mathrm{kN} / \mathrm{m}^{2}$. However, no information was gained about the real maximum weight of materials stored on the deck plate prior to the occurrence of the cracks.

Upon familiarization with the kind of materials stored and with the warehousing height, it was assumed that the real load did not exceed the nominal admissible figures. For such an assumed level of loads, calculations were made for the deck plate as if it were a flat multi-span plate supported on steel binding

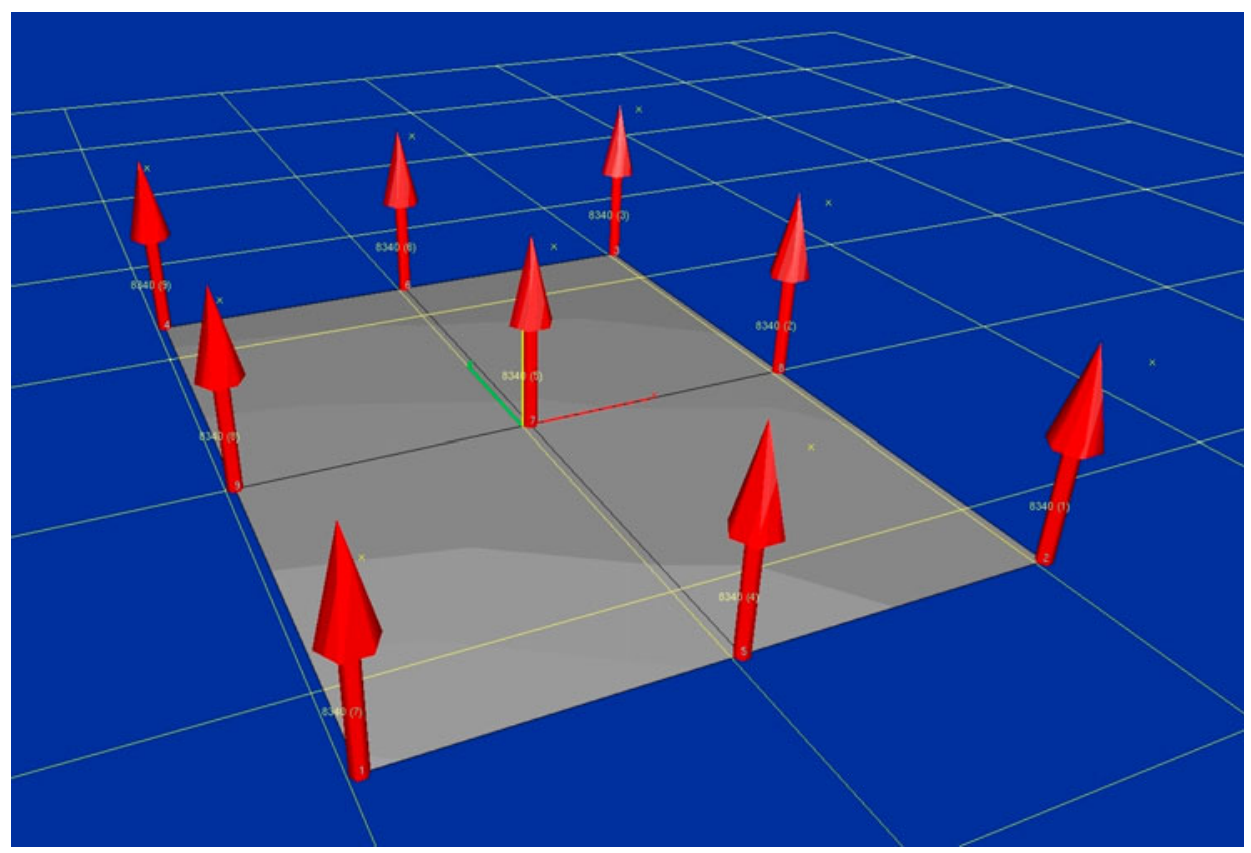

Fig. 15. Position scheme of 9 accelerometers during Operational Modal Analysis (OMA) 


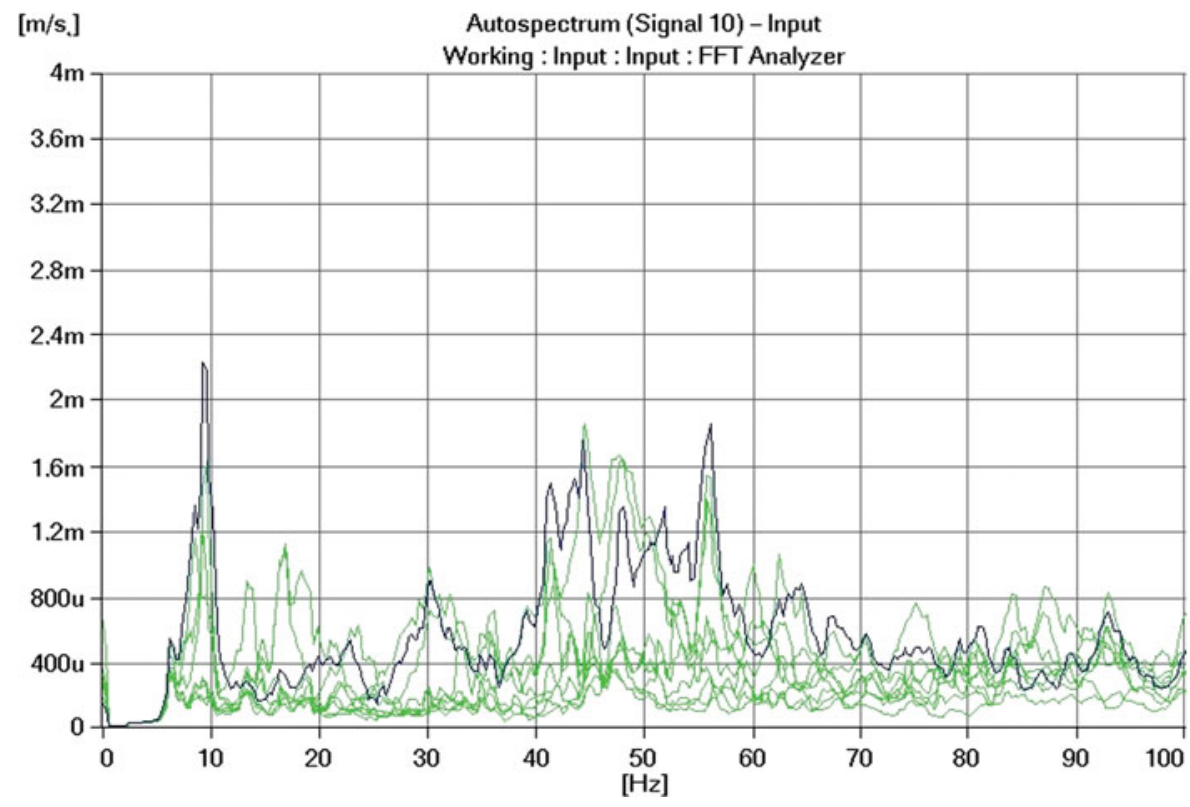

Fig. 16. Autospectrum of acceleration measured on the concrete floor slab, bandwidth $0-100 \mathrm{~Hz}$ (Signal $10-$ blue line, the other signals - green lines)

joists, which are the non-deformable supports for the plate. The values of the internal forces found in this way, even when additional loads from fork-lift car and presses on the deck plate are considered, were found to be ones that would not cause any cracks of the plate.

Hence, the whole structure of the hall, within the segment under consideration, was modelled as a threedimensional unit for real dimensions of steel structure elements (Fig. 18). Furthermore, verifying calculations (Autodesk Robot Structural Analysis 2012) were carried out for a two-dimensional model which takes into account the flexibility of steel load carrying elements of the deck plate, i.e. beams and binding joist. Steel beams are subject to displacements under load. Therefore, the deck plate rests on elastic supports. For the sake of large spans of slab beams, these displacements could have a substantial effect on the distribution of internal forces in the reinforced slab.

To determine the flexibility coefficient, the slab beam was loaded with an evenly distributed unit load. Moreover, since the beams are resting on deformable binding joists, the effect of their deformations on beam flexibility was also considered - in this case, the binding joists were loaded with reactions of the beams resting on them. Calculations made both in a spatial model and in a two-dimensional model gave similar results.

The performed analyses showed that when the calculations take into account the flexibility of slab steel beams, the obtained maximum supporting moments in the reinforced concrete slab resting on them

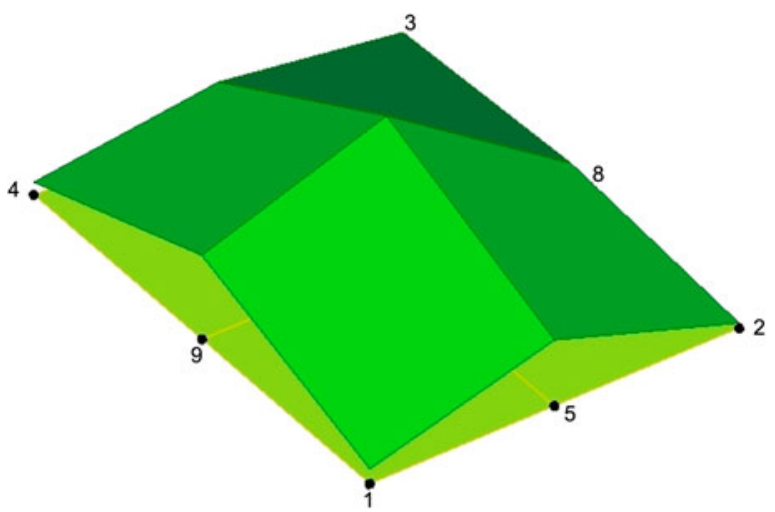

Fig. 17. Identified eigenshape for the fundamental eigenfrequency $(9.27 \mathrm{~Hz})$

are almost twice as great as those resulting from calculations that do not take flexibility into account; the range of their influence is also much larger. This is of special importance in the case under examination, as the additional reinforcement applied over the supports, with total length of $110 \mathrm{~cm}$, is very short.

Detailed calculations proved that while the reinforcement is sufficient along the axis of supports, the moments, just beyond the zone of additional reinforcement influence, are so large that they could cause cracks in the deck plate top surface with the opening about $0.52 \mathrm{~mm}$ wide, so in practice twice as large as those admissible, which amount to $0.3 \mathrm{~mm}$. Taking into consideration the additional load from the fork-lift truck and the presses, the deck plate cracks could amount up to $0.7-0.86 \mathrm{~mm}$. The 


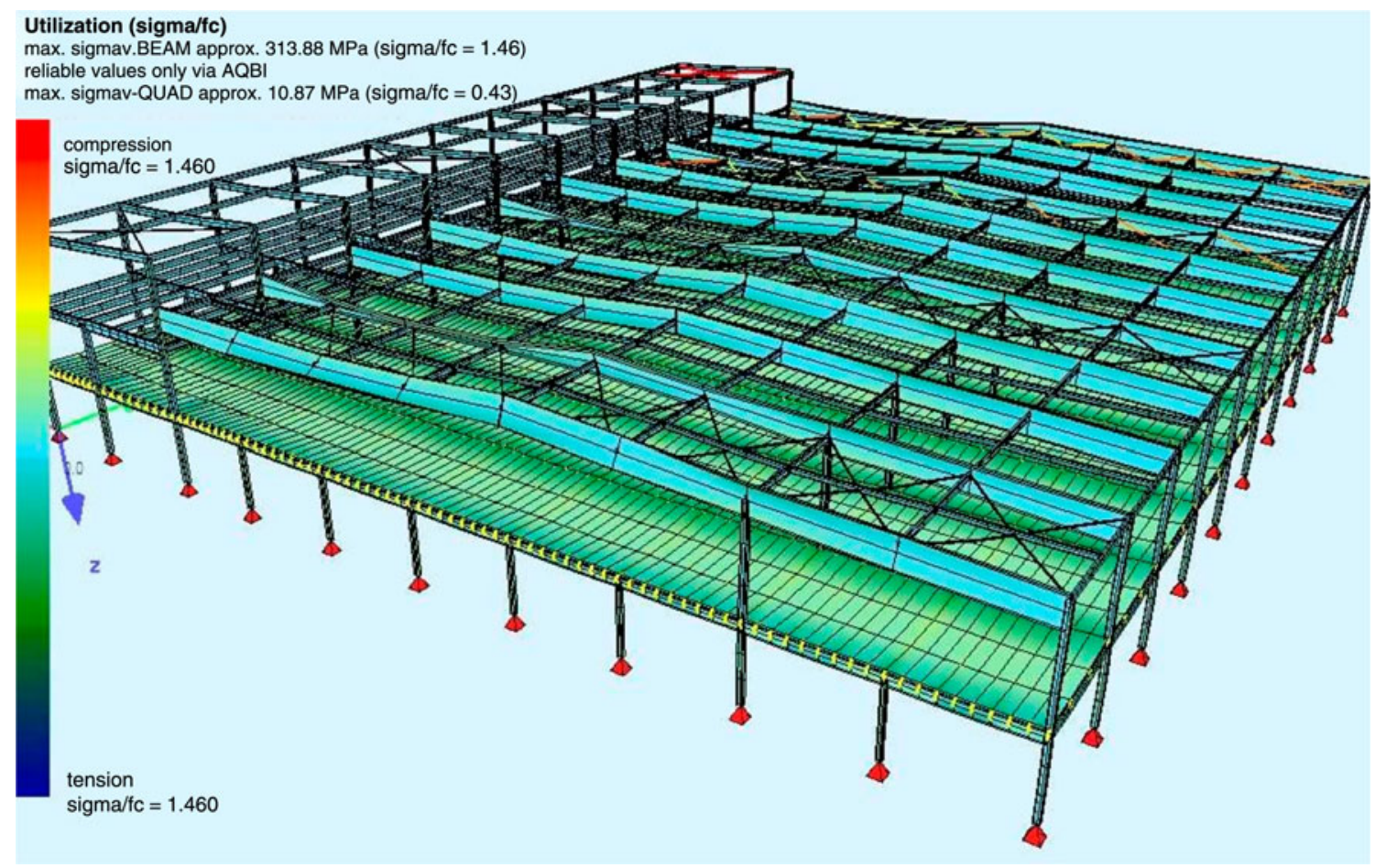

Fig. 18. Example of the stress results for structural analysis

theoretical widths of crack openings and their placement parallel to the steel beams of the deck plate coincide with the opening widths determined by measurements and with the arrangement of cracks observed on the deck plate. It was also proved that for the specified level of loads, cracks could also appear perpendicularly to the main structural system of the deck plate, over the binding joists supported by columns. Such cracks were actually observed over each binding joist within the loaded deck plate.

Because of the occurrence of the cracks, calculations were also made for the load bearing capacity of the RC deck plate considering its lack of continuity over supports. In order to prevent the occurrence of new cracks and due to plate discontinuity in crack areas, the maximum operational load of the deck plate was established at $4 \mathrm{kN} / \mathrm{m}^{2}$, making allowance in the calculations for effect of the steel beams flexibility the deck plate on the redistribution and the values of the bending moments in the deck plate.

Computer calculations of the dynamics of the whole structure were also performed (Figs 19 and 20) and the results were compared with real measurements of eigenvalues of the loaded deck plate for various loads and working conditions (Section 4).

Upon completing a series of measurements, it was found that the actual fundamental eigenvalue for the deck plate is about $9.25 \mathrm{~Hz}$, while the value calculated by the numerical method was $6.56 \mathrm{~Hz}$, which seems to be a sufficiently good approximation of the real values. It was also found, both from measurements and from numerical calculations, that

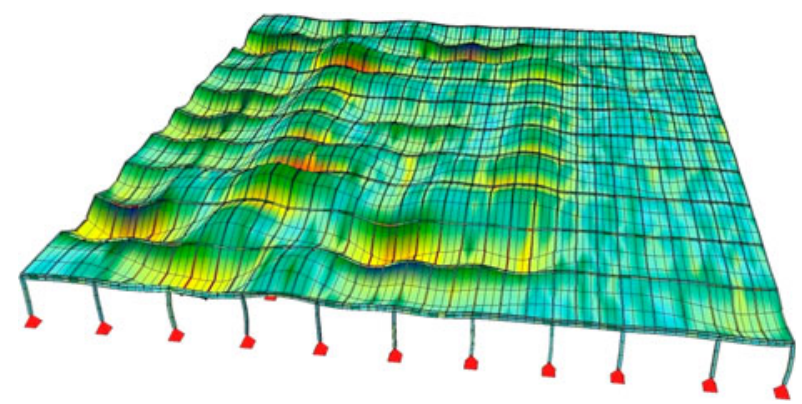

Fig. 19. Example of the results of dynamic calculations for eigenvalue $6.56 \mathrm{~Hz}$

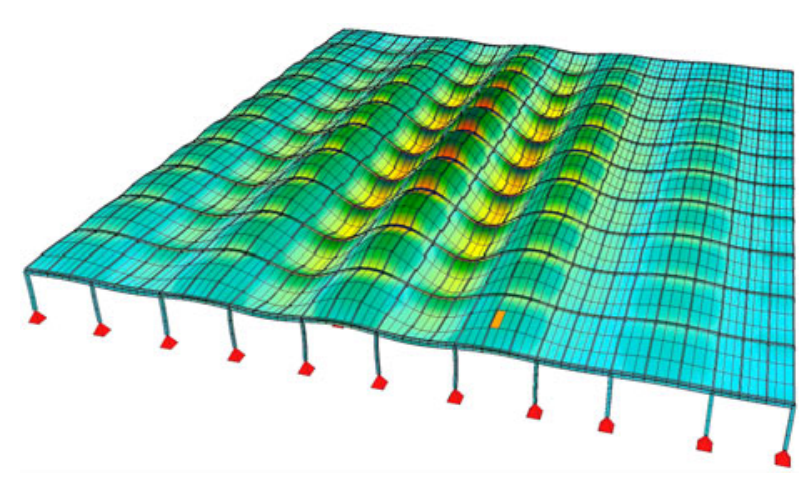

Fig. 20. Example of the results of dynamic calculations for eigenvalue $5.91 \mathrm{~Hz}$

the level of vibrations experienced could cause the development of the cracks in the deck plate. However, the vibration should not have been their direct cause. 


\section{Conclusions}

The cracks in the deck plate under examination were caused by a reinforcement and deck plate thickness that were mismatched to the designed level of operational loads of $8 \mathrm{kN} / \mathrm{m}^{2}$. On the other hand, the steel components of the deck plate, that is, beams and binding joists are of a sufficient design loading capacity for the assumed level of operational loads. Presumably, when the deck plate of the building was designed, the influence of the steel deck plate beam flexibility on the distribution of forces in the RC slab was not taken into account, causing an almost twofold underestimation of the values of support moments.

After the flexibility of the deck plate steel beams had been considered, a numerical simulation found that there is a possibility of cracks appearing in the deck plate with an up to $1 \mathrm{~mm}$ opening, which was the case in the real structure.

The theoretically predicted arrangement of cracks coincided with that of real cracks. An additional load from presses located on the plate, and from a fork-lift servicing the warehouse, caused the enlargement of these cracks. Forced vibrations caused by working presses were not the direct cause for the occurrence of deck plate damages.

However, at the vibration levels recorded, an accelerated degradation of the deck plate was possible due to the enlargement of cracks as the plate operates under a dynamic load. Close to the presses, the admissible level of vibrations as pertaining to the comfort of the workers was found to exceed that specified by the standard (PN-88/B-02171:1988).

As it is necessary to prevent the occurrence of new cracks and due to the discontinuity of plates in the cracked areas, the maximum operational load of the deck plate was established at $4 \mathrm{kN} / \mathrm{m}^{2}$, with the influence of the steel beams of the deck plate on redistribution and values of bending moments in the deck plate taken into account in the calculations. It was also decided not to allow fork-lift trucks to drive over the deck plate.

Due to the vibration level causing discomfort to workers and furthering the development of cracks, a recommendation was made to move the presses from the second storey to the first. As an alternative solution it was proposed to strengthen the second storey slab and use appropriate dampers for presses.

\section{References}

Alam, S. Y.; Loukili, A.; Grondin, F. 2012. Monitoring size effect on crack opening in concrete by digital image correlation, European Journal of Environmental and Civil Engineering 16(7): 818-836.

http://dx.doi.org/10.1080/19648189.2012.672211

Andersen, P.; Brincker, R.; Ventura, C.; Cantieni, R. 2008. Modal estimation of civil structures subject to ambient and harmonic excitation, in Proc. of the 26th Interna- tional Modal Analysis Conference (IMAC), 4-7 February, 2008, Orlando, Florida, USA. 8 p.

ASTM C900-06:2006. Standard test method for pullout strength of hardened concrete. American Society for Testing and Materials International. West Conshohocken, PA, USA. 11 p.

Autodesk Robot Structural Analysis. 2012. Autodesk, 2012.

Breysse, D.; Larget, M.; Sbaratai, Z. M.; Lataste, J.-F.; Balayssac, J. P. 2011. Quality of NDT measurements and accuracy of concrete physical properties quantitative assessment, European Journal of Environmental and Civil Engineering 15(4): 619-632.

Bungey, J.; Millard, S.; Grantham, M. 2006. Testing of concrete structures. $4^{\text {th }}$ ed. London, New York: Taylor and Francis. 352 p.

Chang, P.; Yao, Q. F.; Wang, A. P. 2006. Crack resistance analysis on RC composite floor slab, Key Engineering Materials 302-303: 637-643.

http://dx.doi.org/10.4028/www.scientific.net/KEM. 302-303.637

Crisinel, M.; O’Leary, D. 1996. Composite floor slab design and construction, Structural Engineering International 6(1): 41-46.

http://dx.doi.org/10.2749/101686696780495923

Dmochowski, G.; Berkowski, P.; Schabowicz, K.; Wójcicki, Z.; Grosel, J.; Dłucik, Ł. 2010. Failure analysis of RC floor slab in industrial hall, in Proc. of the 10th International Conference "Modern Building Materials, Structures and Techniques”, 19-21 May, 2010, Vilnius, Lithuania, 587-592.

Dudziński, W.; Pękalski, G.; Harnatkiewicz, P.; Kopczyński, A.; Lorenc, W.; Kożuch, M; Rowiński, S. 2011. Study on fatigue cracks in steel-concrete shear connection with composite dowels, Archives of Civil and Mechanical Engineering 11(4): 839-858.

Ewins, D. J. 2000. Modal testing. Baldock: Research Studies Press Ltd. 562 p.

Felicetti, R. 2010. Assessment of an industrial pavement via the impact acoustics method, European Journal of Environmental and Civil Engineering 14(4): 427-439.

Głodkowska, W. 2011. Forecasting crack resistance of shortand long-term loaded coatings, Archives of Civil and Mechanical Engineering 11(1): 33-44.

Gorzelańczyk, T. 2011a. Moisture influence on the failure of self-compacting concrete under compression, Archives of Civil and Mechanical Engineering 11(1): 45-60. http://dx.doi.org/10.1016/S1644-9665(12)60173-3

Gorzelańczyk, T. 2011b. The effect of moisture content on the failure of self-compacting concrete under compression, as assessed by means of acoustic methods, Archives of Civil and Mechanical Engineering 11(1): 45-60.

http://dx.doi.org/10.1016/S1644-9665(12)60173-3

Gorzelańczyk, T. 2012. Acoustically assessed influence of air pore structure on failure of self-compacting concretes under compression, Journal of Civil Engineering and Management 18(1): 60-70.

http://dx.doi.org/10.3846/13923730.2011.652982

Goszczyńska, B.; Świt, G.; Trạmpczyński, W.; Krampikowska, A.; Tworzewska, J.; Tworzewski, P. 2012. Experimental validation of concrete crack identification and location with acoustic emission method, Archives of 
Civil and Mechanical Engineering 12(1): 23-28.

http://dx.doi.org/10.1016/j.acme.2012.03.004

Hoła, J.; Sadowski, Ł.; Schabowicz, K. 2011. Nondestructive identification of delaminations in concrete floor toppings with acoustic methods, Automation in Construction 20(7): 799-807.

http://dx.doi.org/10.1016/j.autcon.2011.02.002

Hoła, J.; Schabowicz, K. 2005a. New technique of nondestructive assessment of concrete strength using artificial intelligence, NDT \& E International 38(4): 251-259. http://dx.doi.org/10.1016/j.ndteint.2004.08.002

Hoła, J.; Schabowicz, K. 2005b. Methodology of neural identification of strength of concrete, ACI Materials Journal 102(6): 459-464.

Hoła, J.; Schabowicz, K. 2010. State-of-the-art non-destructive methods for diagnostic testing of building structures - anticipated development trends, Archives of Civil and Mechanical Engineering 10(3): 5-18.

Jacobsen, N. J.; Andersen, P.; Brincker, R. 2008. Application of frequency domain curve-fitting in the EFDD technique, in Proc. of the 26th International Modal Analysis Conference (IMAC), 4-7 February, 2008, Orlando, Florida, USA. 13 p.

Johnson, R. P. 2004. Composite structures of steel and concrete. $3^{\text {rd }}$ ed. Oxford: Blackwell Publishing Ltd. $230 \mathrm{p}$.

Łowińska-Kluge, A.; Błaszczyński, T. 2012. The influence of internal corrosion on the durability of concrete, Archives of Civil and Mechanical Engineering 12(2): 219-227.

PN-88/B-02171:1988. Ocena wplywu drgań na ludzi w budynkach [Assessment of vibration influence on people in buildings]. Warsaw: PKN. 8 p.
PN-90/B-03200:1990. Konstrukcje stalowe. Obliczenia statyczne i projektowanie [Steel structures. Static calculations and design]. Warsaw: PKN. 100 p.

PN-EN 12504-3:2006. Badania betonu $w$ konstrukcjach Częsć 3: Oznaczanie sity wyrywajacej [Examination of concrete in structures - part 3: determination of pull-out force]. Warsaw: PKN. 12 p.

PN-EN 13791:2008. Ocena na budowie wytrzymałosci na sciskanie betonu $w$ konstrukcji $i$ w elementach prefabrykowanych [Determination in situ of compressive strength in structures and prefabricated structural elements]. Warsaw: PKN. 135 p.

Report ACI 228.2R98. 1998. Nondestructive test methods for evaluation of concrete in structures. Farmington Hills, MI: ACI. 62 p.

Sansalone, M.; Streett, W. B. 1997. Impact-echo: Nondestructive evaluation of concrete and masonry. Ithaca, NY: Bullbrier Press. 339 p.

Schabowicz, K.; Hoła, J. 2012. Nondestructive elastic-wave tests of foundation slab in office building, Materials Transactions 53(2): 296-302. http://dx.doi.org/10.2320/matertrans.I-M2011845

Stawiski, B. 2012. The heterogeneity of mechanical properties of concrete in formed constructions horizontally, Archives of Civil and Mechanical Engineering 12(1): 90-94. http://dx.doi.org/10.1016/j.acme.2012.03.006

Valivonis, J. 2006. Analysis of behaviour of contact between the profiled steel sheeting and the concrete, Journal of Civil Engineering and Management 12(3): 187-194.

Piotr BERKOWSKI. PhD, Eng., Assistant Professor at the Civil Engineering Faculty, Wroclaw University of Technology. He is working in the Division of Building Physics and Computational Methods of the Building Engineering Institute. Member of the Polish Association of Civil Engineers and Technicians and Polish Society of Theoretical and Applied Mechanics. His research interests are related to: optimization of building structures, applications of numerical methods in structural analysis, and revitalization of heritage buildings.

Grzegorz DMOCHOWSKI. PhD, Eng., Assistant Professor at the Civil Engineering Faculty, Wroclaw University of Technology. He is working in the Division of Building Physics and Computational Methods of the Building Engineering Institute. Member of the Polish Association of Civil Engineers and Technicians. His research interests focus on structural design, RC structures, computational methods, and on practical aspects of historical buildings repair and revitalization.

Jacek GROSEL. PhD, Eng., Assistant Professor in the Structural Dynamics Division of the Institute of Civil Engineering, Wroclaw University of Technology. Member of the Polish Association of Civil Engineers and Technicians. Research interests include static and dynamic MES modelling, measurements techniques and dynamic analysis of constructions based on measurements.

Krzysztof SCHABOWICZ. PhD, Eng., Assistant Professor in the General Building Division of the Building Engineering Institute, Faculty of Civil Engineering, Wroclaw University of Technology. Member of the Polish Association of Civil Engineers and Technicians and Polish Association of Building Mycology. His research interests include concrete, ultrasonic tomography, impact-echo, impulse-response, GPR and other non-destructive tests, artificial intelligence.

Zbigniew WOJCICKI. Dr Sc., PhD, Eng., Professor, Head of the Structural Dynamics Division of the Institute of Civil Engineering, Wroclaw University of Technology. Member of the International Association of Applied Mathematics and Mechanics. Research interests include parametric vibrations, dynamic reduction of vibrations, static and dynamic numerical MES modelling, measurements and dynamic analysis of constructions. 